[7] Experimental procedure: $2: 30 \% \mathrm{H}_{2} \mathrm{O}_{2}(11.3 \mathrm{~g}, 100 \mathrm{mmol})$ was added with stirring to ethyl pyruvate $(17.3 \mathrm{~g}, 150 \mathrm{mmol})$ at -10 to $0^{\circ} \mathrm{C}$ [3]. This solution was then added with stirring and cooling $\left(-5\right.$ to $0^{\circ} \mathrm{C}$ ) to a mixture of $\mathrm{I}(10 \mathrm{mmol})$, conc. $\mathrm{H}_{2} \mathrm{SO}_{4}(3 \mathrm{~g}), \mathrm{H}_{2} \mathrm{O}(8 \mathrm{~g}), \mathrm{FeSO}_{4} \cdot 7 \mathrm{H}_{2} \mathrm{O}(28 \mathrm{~g}$, $100 \mathrm{mmol})$, and $\mathrm{CH}_{2} \mathrm{Cl}_{2}(150 \mathrm{~mL})$. After $15 \mathrm{~min}$ of further stirring, the resulting mixture was poured into ice water, the phases were separated, and the aqueous phase was exhaustively extracted with $\mathrm{CH}_{2} \mathrm{Cl}_{2}$. After drying over anhydrous $\mathrm{Na}_{2} \mathrm{SO}_{4}$, the solvent and excess ethyl pyruvate were removed in vacuo. The spontaneously crystallizing, colorless needles were recrystallized from diethyl ether: Yield: $1.4 \mathrm{~g} \mathrm{(81 \% )} \mathbf{2}$; $\mathrm{mp}=89-93^{\circ}$ : correct $\mathrm{C}, \mathrm{H}, \mathrm{N}$ analyses. IR $(\mathrm{KBr}): 1715\left(v_{\mathrm{c}-\mathrm{o}}\right), 2250 \mathrm{~cm}^{-}$ $\left(v_{C=N}\right):$ MS: $m / z \quad 176\left(2 \%, M^{+}\right), 104(100 \%)$; 'H-NMR $\left(\mathrm{CDCl}_{3}, 90\right.$ $\mathrm{MHz}): \delta=9.00(\mathrm{~d}, 1 \mathrm{H}, J=5 \mathrm{~Hz}, \mathrm{H}-6), 8.39(\mathrm{~d}, 1 \mathrm{H}, J=2 \mathrm{~Hz}, \mathrm{H}-3), 7.75$ (dd, $1 \mathrm{H}, J=5 \mathrm{~Hz}, 2 \mathrm{~Hz}, \mathrm{H}-5), 4.53\left(\mathrm{q}, 2 \mathrm{H}, J=7 \mathrm{~Hz}, \mathrm{CH}_{2}\right), 1.48(\mathrm{t}, 3 \mathrm{H}$, $J=7 \mathrm{~Hz}, \mathrm{CH}_{3}$ ).

[8] 8-10, 12: $30 \% \mathrm{H}_{2} \mathrm{O}_{2}(3.4 \mathrm{~g}, 30 \mathrm{mmol})$ was added with stirring to ethyl pyruvate $(5.2 \mathrm{~g}, 45 \mathrm{mmol})$ at -10 to $0^{\circ} \mathrm{C}$ [3]. This solution was then added with stirring and cooling $\left(-5\right.$ to $\left.0^{\circ} \mathrm{C}\right)$ to a mixture of 7 or $11(10$ mmol). conc. $\mathrm{H}_{2} \mathrm{SO}_{4}(3 \mathrm{~g}), \mathrm{H}_{2} \mathrm{O}(8 \mathrm{~g}), \mathrm{FeSO}_{4} \cdot 7 \mathrm{H}_{2} \mathrm{O}(8.3 \mathrm{~g} .30 \mathrm{mmol})$, and $\mathrm{CH}_{2} \mathrm{Cl}=(30 \mathrm{~mL})-\mathbf{- 8}-\mathbf{1 0}$ : After a work-up similar to that for 2, the residue is separated by medium pressure chromatography (Lobar size B, LiChroprep ${ }^{\text {SI }}$ Si60, Merck; dichloromethane/ethyl acetate $\left.5: 1\right)$. Fraction I: $394 \mathrm{mg} 10$ [11] (22\%); fraction II : $580 \mathrm{mg} 9$ [10] (33\%); fraction IIl: $366 \mathrm{mg} 8$ [9] (21\%). - 12: After washing the spontaneously crystallizing, pale yellow needles with diisopropyl ether, $1.2 \mathrm{~g} \mathrm{(80 \% )}$ of the product is obtained, whose spectroscopic data are identical with those of authentic material [12].

[9] 8: Structure determination on the basis of the $H-N M R$ spectrum $\left\{\mathrm{CDCl}_{1}, 90 \mathrm{MHz}: \delta=9.10-8.90(\mathrm{~m}, 1 \mathrm{H}, \mathrm{H}-6), 8.38-8.18(\mathrm{~m}, 1 \mathrm{H}, \mathrm{H}-4)\right.$, $7.83-7.60(\mathrm{~m}, 1 \mathrm{H}, \mathrm{H}-5), 4.58\left(\mathrm{q}, 2 \mathrm{H}, J=7 \mathrm{~Hz}, \mathrm{CH}_{2}\right), 1.49(\mathrm{t}, 3 \mathrm{H}, J=7 \mathrm{~Hz}$, $\left.\mathrm{CH}_{3}\right)$ as well as the hydrolysis in $2 \mathrm{~N} \mathrm{Na}_{2} \mathrm{CO}_{3}$ solution to 3-cyano-2-pyridinecarboxylic acid [13].

[10] L. Novacek, K. Palat, M. Celadnik, E. Matuskova, Cesk. Farm. 1$]$ (1962) 76; Chem. Abstr. 57 (1962) 15067 i.

[11] H. Watanabe, Y. Kikugawa, S. Yamada, Chem. Pharm. Bull. 21 (1973) 465.

[12] H. Shindo, Chem. Pharm. Bull 8 (1960) 33

[13] S. Fallab, H. Erlenmeyer, Helv. Chim. Acta 34 (1951) 488.

\section{Proton Exchange between Arenium Ions and Arenes in the Gas Phase**}

\section{By Dietmar Kuck,* Steen Ingemann, Leo J. de Koning,}

\section{Hans-Friedrich Grützmacher, and Nico M. M. Nibbering}

Proton transfer reactions are known to be extremely fast

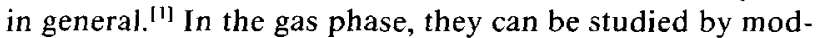
ern, time-resolved mass spectrometry. Thus, MIKE spectrometry of metastable ions $\mathrm{s}^{[2]}$ (time scale $10^{-5}$ to $10^{-4} \mathrm{~s}$ ) is used for the investigation of intramoleculat hydrogen migration reactions, e.g., the proton exchange in protonated $\alpha, \omega$-diphenylalkanes [Eq. (1a)], ${ }^{[3]}$ while, for intermolecular exchange reactions, ${ }^{[4]}$ Fourier transform ion cyclotron resonance (FT-ICR) spectrometry ${ }^{[5]}$ is becoming increasingly important (time scale $10^{-3}$ to $10^{+1} \mathrm{~s}$ ). We report here on the intermolecular proton exchange [Eq. (1b)] between simple arenium ions and arenes ${ }^{[4 c]}$ in the cell of a FT-ICR mass spectrometer ${ }^{[6]}\left(\mathrm{Ar}, \mathrm{Ar}^{\prime}=\right.$ aryl $)$.

$\mathrm{ArH}^{\oplus}-\left(\mathrm{CH}_{2}\right)_{\mathrm{n}}-\mathrm{Ar}^{\prime} \rightleftharpoons \mathrm{Ar}-\left(\mathrm{CH}_{2}\right)_{\mathrm{n}}-\mathrm{Ar}^{\prime} \mathrm{H}^{\oplus}$
$2 \leq \mathrm{n} \leq 20$

$\mathrm{ArH}_{2}^{\oplus}+\mathrm{Ar}^{\prime} \mathrm{H} \rightleftharpoons \mathrm{ArH}+\mathrm{Ar}^{\prime} \mathrm{H}_{2}^{\oplus}$

[*] Dr. D. Kuck, Prof. Dr. H.-F. Grützmacher

Fakultät für Chemie der Universität

Postfach 86 40, D-4800 Bielefeld 1 (FRG)

Prof. Dr. N. M. M. Nibbering, Dr. S. Ingemann, L. J. de Koning

Laboratorium voor Organische Scheikunde, Universiteit van Amsterdam

Nieuwe Achtergracht 129, NL-1018 WS Amsterdam (The Netherlands)

$I^{* * j} D . K$. thanks the Deutscher Akademischer Austauschdienst, Bonn, and the Ministerie voor Onderwijs en Wetenschappen, The Hague, for a grant.

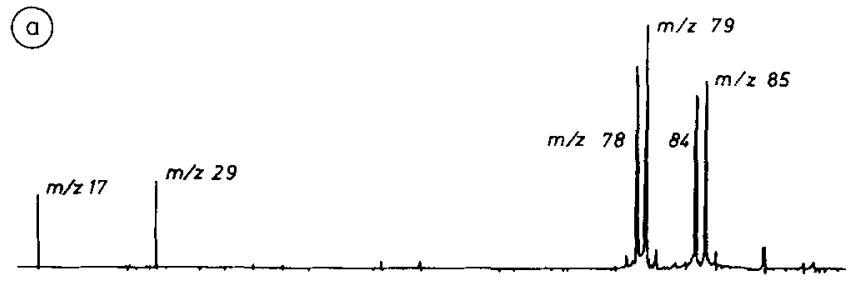

(b)
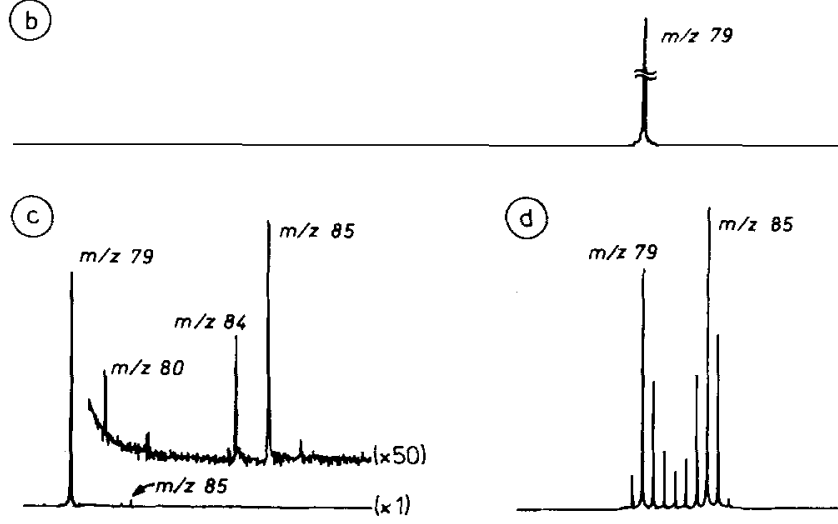

Fig. I. a) HT-ICR mass spectrum of a mixture of $\left(\mathrm{H}_{4}, \mathrm{C}_{1} \mathrm{H}_{6}, \text { and } \mathrm{C}_{6}, \mathrm{D}\right)_{6},[7 \mathrm{a}]$; b) after ejection of all ions except $C_{6} H_{7}(m / z 79)$ at the time $\left.t_{r}=0 ; c\right)$ after $t_{\mathrm{r}}=190 \mathrm{~ms}$, and d) after $t_{\mathrm{r}}=6290 \mathrm{~ms}$.

We generated the benzenium ions $\mathrm{C}_{6} \mathrm{H}_{7}^{\oplus}$ and $\mathrm{C}_{6} \mathrm{HD}_{6}^{\oplus}$ by electron-impact ionization of a mixture of benzene, $\left[D_{6}\right]$ benzene, and methane at $10^{-4} \mathrm{~Pa}$ (Fig. 1a). ${ }^{[701}$ All ions except $\mathrm{C}_{6} \mathrm{H}_{7}^{\oplus}(m / z 79)$ were then removed from the ICR cell by "notch ejection"|[8] (Fig. 1b); subsequently, the ionmolecule reactions of the benzenium ions isolated in this way with the $\mathrm{C}_{6} \mathrm{H}_{6} / \mathrm{C}_{6} \mathrm{D}_{6}$ mixture were followed as a function of time $\left(t_{\mathrm{r}}\right)$. Figures $1 \mathrm{c}$ and $\mathrm{id}$ show all ions present in the cell at $t_{\mathrm{r}}=190$ and $6290 \mathrm{~ms}$, respectively; Figure 2 displays the dependence of the relative abundance of the product ions $\mathrm{C}_{6}(\mathrm{H}, \mathrm{D}){ }_{7}^{\oplus}$ on $t_{\mathrm{r}}$.

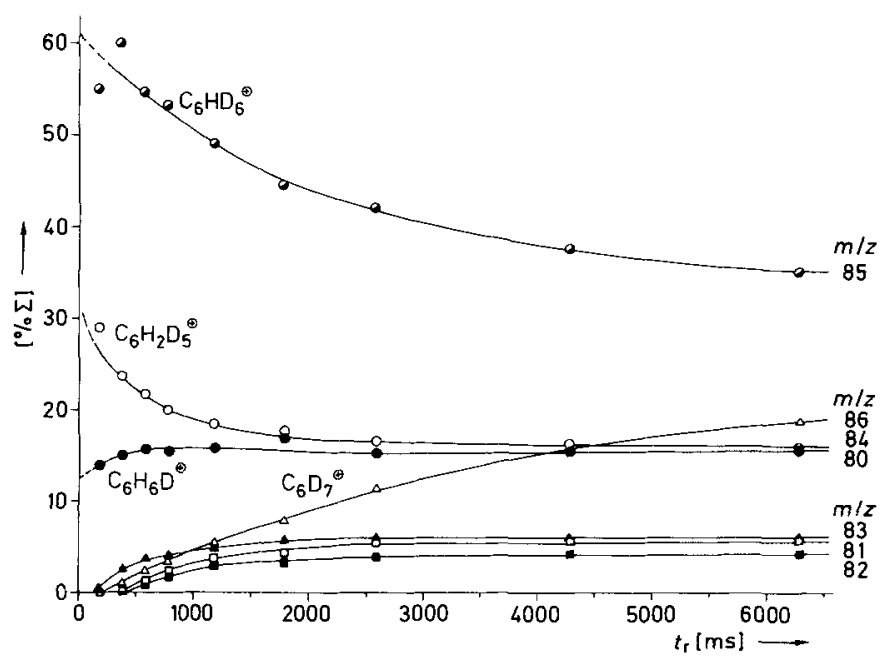

Fig. 2. Relative abundances of the product ions in the system $\mathrm{C}_{6} \mathrm{H}_{7}, \mathrm{C}_{6} \mathrm{H}_{6}$ $\mathrm{C}_{6} \mathrm{D}_{6}$ as a function of the reaction time $t_{\mathrm{r}}$ given relative to the sum of all product ions and corrected for naturally occurring ${ }^{13} \mathrm{C}$.

The measurements allow two conclusions to be drawn:

1. The proton exchange between benzenium ions and benzene is a surprisingly slow process (cf., for example, the system $\mathrm{D}_{3} \mathrm{O}^{\oplus} / \mathrm{C}_{6} \mathrm{H}_{6}^{[4 a]}$ ). For short reaction times $t_{r}$ (under 
"single collision conditions"), no isotopomers other than $\mathrm{C}_{6} \mathrm{HD}_{6}^{\oplus}$ (simple $\mathrm{H}^{\oplus}$ transfer), $\mathrm{C}_{6} \mathrm{H}_{6} \mathrm{D}^{\oplus}$ (simple $\mathrm{H}^{\oplus} / \mathrm{D}^{\oplus}$ exchange), and $\mathrm{C}_{6} \mathrm{H}_{2} \mathrm{D}_{5}^{\oplus[9]}$ are formed. The light and the heavy benzenium ions also predominate under "multiple collision" conditions $\left(t_{\mathrm{r}} \gtrsim 300 \mathrm{~ms}\right)$.

2 . The proton exchange occurs not only by consecutive ion-molecule reactions, but also within the collision complexes (e.g., $\left[\mathrm{C}_{6} \mathrm{H}_{7}^{\oplus} \cdot \mathrm{C}_{6} \mathrm{D}_{6}\right]^{*}$ ). This follows from extrapolation of the relative abundances of the product ions to $t_{\mathrm{r}}=0$ : The exchange products $\mathrm{C}_{6} \mathrm{H}_{6} \mathrm{D}^{\oplus}(m / z \quad 80)$ and $\mathrm{C}_{6} \mathrm{H}_{2} \mathrm{D}_{5}^{\oplus}(m / z$ 84) are already present there (Fig. 2).

Similar results are obtained from the corresponding investigation of the reaction of isolated $\mathrm{C}_{6} \mathrm{HD}_{6}^{\oplus}$ ions with the $\mathrm{C}_{6} \mathrm{H}_{6} / \mathrm{C}_{6} \mathrm{D}_{6}$ mixture.

A further experiment allows a clear distinction to be made between these two exchange processes (Scheme 1). If the ions $\mathrm{C}_{6} \mathrm{HD}_{6}^{\oplus}(m / z 85)$ are continuously removed from the cell for the entire reaction time, ${ }^{[7 \mathrm{~b}]}$ the formation of all further $\mathrm{C}_{6}(\mathrm{H}, \mathrm{D})_{7}^{\oplus}$ ions is suppressed to the extent that they are formed via $\mathrm{C}_{6} \mathrm{HD}_{6}^{\oplus}$ (Scheme 1a). In contrast, $\mathrm{C}_{6}(\mathrm{H}, \mathrm{D})_{7}^{\oplus}$ ions that arise via $\mathrm{H}^{\oplus} / \mathrm{D}^{\oplus}$ exchange within the collision complexes $\left[\mathrm{C}_{6} \mathrm{H}_{7}^{\oplus}, \mathrm{C}_{6} \mathrm{D}_{6}\right]^{*}$ are not suppressed (Scheme $1 \mathrm{~b}$ ). In Table 1 the relative abundances of the ions present in the cell after $t_{\mathrm{r}}=790 \mathrm{~ms}-$ with and without continuous removal of the ions $m / z 85$-are compared.

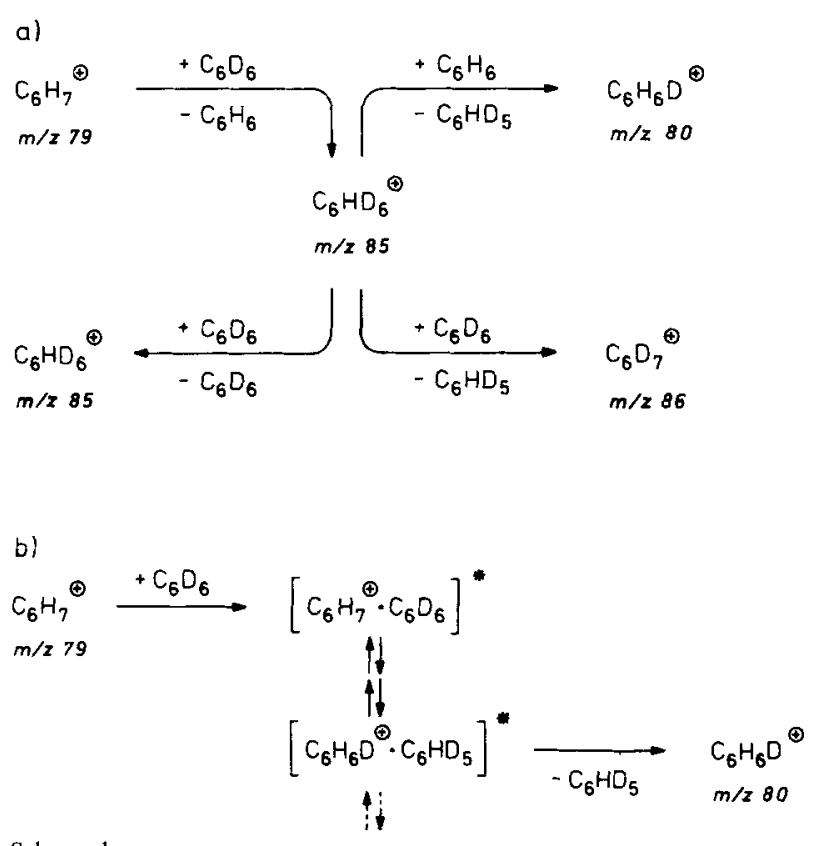

Scheme 1.

Table 1. Ion abundances in the system $\mathrm{C}_{6} \mathrm{H}_{7}^{\oplus} / \mathrm{C}_{6} \mathrm{H}_{6} / \mathrm{C}_{6} \mathrm{D}_{6}$ after $t_{\mathrm{r}}=790 \mathrm{~ms}$ without $(-)$ and with $(+)$ continuous removal of the ions $\mathrm{C}_{6} \mathrm{HD}_{6}^{\oplus}(\mathrm{m} / z \mathrm{85})$ [a].

\begin{tabular}{rrrrrrrrrr}
\hline$m / z$ & 78 & 79 & 80 & 81 & 82 & 83 & 84 & 85 & 86 \\
\hline$(-)$ & 30 & 1000 & 49 & 8.6 & 7.9 & 14.3 & 70 & 168 & 15.8 \\
$(+)$ & 30 & 1000 & 40 & 6.4 & 4.2 & 10.4 & 62 & 0 & 1.0 \\
\hline
\end{tabular}

[a] ${ }^{13} \mathrm{C}$-corrected values. The absolute abundance of the ions $\mathrm{C}_{6} \mathrm{H}_{7}^{\oplus}(\equiv 1000)$ was constant in both experiments. In order to continuously remove the ions $\mathrm{C}_{6} \mathrm{HD}_{6}^{9}$, a radiofrequency pulse with an amplitude of $2.5 \mathrm{~V}$ peak-to-peak was used.

The data confirm that the proton exchange takes place within the collision complex: even upon ejection of the ions $m / z$ 85, all $\mathrm{C}_{6}(\mathrm{H}, \mathrm{D})_{7}^{\oplus}$ isotopomers are formed, albeit in lower absolute abundances. Thus, for example, the abundance of the ions $\mathrm{C}_{6} \mathrm{H}_{6} \mathrm{D}^{\oplus}(m / z 80)$ decreases by only a relative $19 \%$; in contrast, the formation of the ions $\mathrm{C}_{6} \mathrm{D}_{7}^{\oplus}(m / z 86)$, which are formed exclusively by consecutive ion-molecule reactions (Scheme 1a), is completely suppressed. ${ }^{[10]}$

The proton exchange between toluenium ions and toluene $\left(\mathrm{C}_{7} \mathrm{H}_{8} / \mathrm{C}_{7} \mathrm{D}_{8} / \mathrm{CD}_{4}\right)^{[7 \mathrm{il}]}$ is even slower than that between the lower homologues. Here, too, the exchange takes place partly within the collision complexes (e.g., $\left.\left[C_{7} D_{9}^{\oplus} \cdot C_{7} H_{8}\right]^{*}\right)$. Thus, a fraction of the $C_{7}(H, D)_{9}^{\oplus}$ isotopomers are still formed despite continuous removal of the ions $\mathrm{C}_{7} \mathrm{H}_{8} \mathrm{D}^{\oplus}$. A possible reason is that the proton exchange in the collision complex $\left[\mathrm{C}_{7} \mathrm{H}_{9}^{\oplus} \cdot \mathrm{C}_{7} \mathrm{H}_{8}\right]^{*}$ only occurs between positions having the same proton affinity (primarily para $\rightleftarrows$ para'), which must lead to a considerable slowing of the reaction compared with the exchange in the collision complex $\left[\mathrm{C}_{6} \mathrm{H}_{7}^{\oplus} \cdot \mathrm{C}_{6} \mathrm{H}_{6}\right]^{*}$.

In fact, no proton exchange is observed for non-degenerate proton-transfer reactions, such as in the system benzene/toluene/methane. ${ }^{[7 a l}$ Accordingly, solely proton transfer is observed at all $t_{\mathrm{r}}$ in the exothermic direction of the reaction [Eq. (2a)], and no other toluene isotopomers are formed in the endothermic direction of the reaction [Eq. (2b)]. ${ }^{[1]}$

$$
\begin{aligned}
& \mathrm{C}_{6} \mathrm{D}_{7}^{\oplus}+\mathrm{C}_{7} \mathrm{H}_{8} \longrightarrow \mathrm{C}_{6} \mathrm{D}_{6}+\mathrm{C}_{7} \mathrm{H}_{8} \mathrm{D}^{\oplus} \\
& \# \mathrm{C}_{6}(\mathrm{H}, \mathrm{D})_{7}^{\oplus} \text { and } \mathrm{C}_{7} \mathrm{H}_{7} \mathrm{D}_{2}^{\oplus} \text { etc. } \\
& \mathrm{C}_{7} \mathrm{H}_{9}^{\oplus}+\mathrm{C}_{6} \mathrm{D}_{6} \# \rightarrow \mathrm{C}_{7}(\mathrm{H}, \mathrm{D})_{9}^{\oplus}+\mathrm{C}_{6}(\mathrm{H}, \mathrm{D})_{6}
\end{aligned}
$$

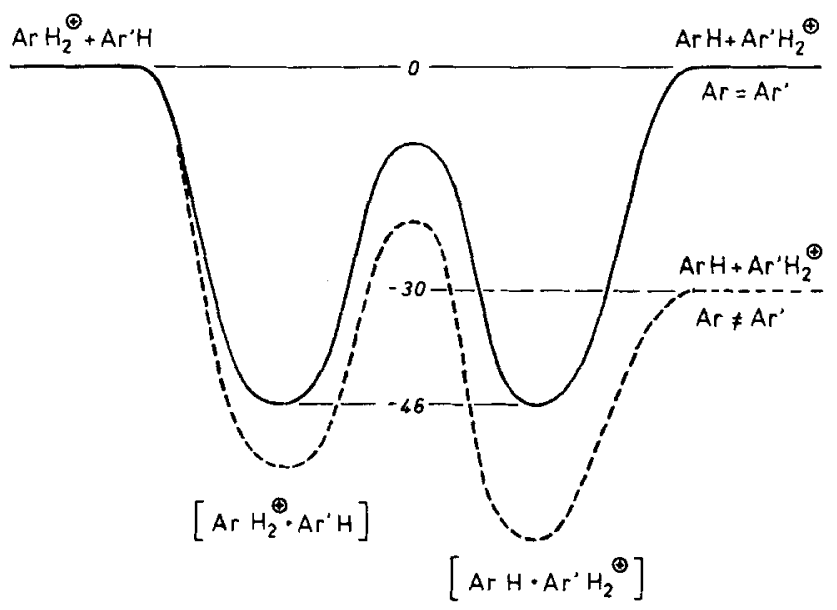

Fig. 3. Energy profiles for the $\|$ transter between arenium ions and arenes (enthalpy values $[1 \mathrm{l}, 13]$ in $\mathrm{kJ} / \mathrm{mol}^{-1}$ ). (-): thermoneutral $\mathbf{H}^{\oplus}$ transfer, $\mathrm{Ar}=\mathrm{Ar}^{\prime}=\mathrm{C}_{6} \mathrm{H}_{5}$ or $\mathrm{C}_{6} \mathrm{H}_{4} \mathrm{CH}_{3} ;(\cdots)$ : non-thermoneutral $\mathrm{H}^{\oplus}$ transfer, $\mathrm{Ar}=\mathrm{C}_{6} \mathrm{H}_{5}, \mathrm{Ar}^{\prime}=\mathrm{C}_{6} \mathrm{H}_{4} \mathrm{CH}_{3}$.

These observations can be explained qualitatively by a symmetrical $\left(\mathrm{A} r=A r^{\prime}\right)$ or an asymmetrical $\left(\mathrm{Ar} \neq \mathrm{Ar} \mathrm{r}^{\prime}\right)$ double-minimum energy profile ${ }^{[12]}$ (Fig. 3). ${ }^{[13]}$ According to our results, the activation barrier between the minima $\left[\mathrm{ArH}_{2}^{\oplus} \cdot \mathrm{Ar}^{\prime} \mathrm{H}\right]$ and $\left[\mathrm{ArH} \cdot \mathrm{Ar}^{\prime} \mathrm{H}_{2}^{\oplus}\right]$ must be relatively high. This is especially noteworthy in comparison with the extremely fast intramolecular proton exchange in protonated $\alpha, \omega$-diphenylalkanes and related arenium ions. ${ }^{[3]}$

Received: February 20, 1985 . revised: May 24, 1985 [Z 1180 [E] German version: Angew. Chem. 97 (1985) 691

CAS Registry numbers:

benzenium, 38815-08-6; benzene, 71-43-2; toluenium, 52809-63-9; toluene, 108-88-3. 
[1] a) R. P. Bell: The Proton in Chemistry, 2nd ed., Cornell University Press, New York 1973; b) M. Eigen, Angew. Chem. 75 (1963) 489; Angew Chem. Int. Ed. Engl. 3 (1964) I; c) J. E. Crooks in E. Caldin, V. Gold (Eds.): Proton Transfer Reactions. Wiley, New York 1975, chap. 6.

[2] a) R. G. Cooks, J. H. Beynon, R. M. Caprioli, G. Lester: Metastable Ions, Elsevier, Amsterdam 1973; b) K. Levsen: Fundamental Aspects of Mass Spectrometry. Verlag Chemie, Weinheim 1978.

[3] a) D. Kuck, Int. J. Mass Spectrom. Ion Phys. 47 (1983) 499; b) D. Kuck W. Bäther, H. F. Grützmacher, J. Am. Chem. Soc. 101 (1979) 7154; c) D. Kuck, W. Bäther, H. F. Grützmacher, Int. J. Spectrom. Ion Proc., in press.

[4] a) B. S. Freiser, R. L. Woodin, J. L. Beauchamp, J. Am. Chem. Soc. 97 (1975) 6893 ; b) S. Ghaderi, P. S. Kulkarni, E. B. Ledford, Jr., C. L. Wilkins, M. L. Gross, Anal. Chem. 53 (1981) 428; c) Y. Yamamoto, S. Takamuku, H. Sakurai, Chem. Lett. 1974, 849;1975, 683

[5] a) C. L. Johlman, R. L. White, C. L. Wilkins, Mass Spectrom. Rev. 2 (1983) 389 ; b) M. L. Gross, D. L. Rempel, Science 226 (1984) 261; c) N. M. M. Nibbering, Nachr. Chem. Tech. Lab. 32 (1984) 1044; d) K. P. Wanczek, Int. J. Mass Spectrom. Ion Proc. 60 (1984) 11.

[6] The FT-ICR mass spectrometer was built at the University of Amsterdam. a) Electronics: J. H. J. Dawson in H. Hartmann, K. P. Wanczek: Lecture Notes in Chemistry, Vol. 31, Springer, Berlin 1982, p. 331; b) software: A. J. Noest, C. W. F. Kort, Comput. Chem. 6 (1982) 111, 115; c) general methods of measurement: J. C. Kleingeld, N. M. M. Nibbering, Org. Mass Spectrom. 17 (1982) 136; S. Ingemann, N. M. M. Nibbering, S. A. Sullivan, C. H. DePuy, J. Am. Chem. Soc. 104 (1982) 6520.

[7] a) Experimental conditions: The magnetic field strength was $1.4 \mathrm{~T}$ in all experiments. The cell of the FT-ICR mass spectrometer [6] was filled with $\approx 1 \cdot 10^{-5} \mathrm{~Pa}$ of each of the two arenes and with $\approx 8 \cdot 10^{-5} \mathrm{~Pa}$ of methane. $\mathrm{CH}_{5}^{\oplus}$ and $\mathrm{C}_{2} \mathrm{H}_{5}^{\oplus}$ ions, among others, were generated by an electron pulse ( $20 \mathrm{eV}, 5 \mathrm{~ms}$ ); they protonated the arenes in the following 200 $m s$ to give $\mathrm{ArH}_{2}^{\oplus}$ and $\mathrm{Ar}^{\prime} \mathrm{H}_{2}^{\oplus}$. Subsequently, all ions except $\mathrm{ArH}_{2}^{\oplus}$ (or $\mathrm{Ar}^{\prime} \mathrm{H}_{2}$ ) were removed from the cell by "notch ejection" [8] (radiofrequency pulse with a scan length of $10 \mathrm{~ms}$ ); then, in the following reaction time $\left(t_{\mathrm{r}}=0\right.$ to $\left.t_{\mathrm{r}}=6290 \mathrm{~ms}\right)$, the ions formed from $\mathrm{ArH}_{2}^{(0)}\left(\mathrm{Ar} \mathrm{Ar}_{2}^{\top}\right)$, $\mathrm{ArH}$ and $\mathrm{Ar}^{\prime} \mathrm{H}$ were measured. b) By applying a radiofrequency pulse for $m / z 85$ (amplitude $3.5 \mathrm{~V}$ peak-to-peak) during the entire reaction time $t_{\mathrm{r}}$, all ${ }^{12} \mathrm{C}_{6} \mathrm{HD}_{6}^{\oplus}$ jons were removed from the cell within $\leqslant 300 \mu \mathrm{s}$ after their formation. During this time, no collisions with molecules of the gas mixture took place (average rate of collision $\approx 10 \mathrm{~s}^{-1}$ ).

[8] a) A. J. Noest, C. W. F. Kort, Comput. Chem. 7 (1983) 81 ; b) J. C. Kleingeld, N. M. M. Nibbering, Tetrahedron 39 (1983) 4193; c) A. G. Marshall, T. C. Lin Wang, T. Lebatnan Ricca, Chem. Phys. Lett. 105 (1984) 233.

[9] A fraction of the ions $m / z \quad 84$ are $\mathrm{C}_{6} \mathrm{D}_{6}^{\oplus \odot}$ molecular ions formed by charge exchange (cf, $m / z 78, \mathrm{C}_{0} \mathrm{H}_{6}^{\mathrm{g}}$ : Table 1).

[10] The ions ${ }^{13} \mathrm{C}^{12} \mathrm{C}_{5} \mathrm{HD}_{6}^{(9)}\left(\mathrm{m} / z\right.$ 86, rel, abundance $0.066\left[{ }^{12} \mathrm{C}_{6} \mathrm{HD}_{6}^{\odot}\right]$ were not ejected and therefore generated ca. $1 / 16$ th of the $\mathrm{C}_{6} \mathrm{D}_{7}^{9}$ ions formed without ejection of $m / z 85$.

[1 1] $\mathrm{PA}\left(\mathrm{C}_{6} \mathrm{H}_{6}\right)=777 \mathrm{~kJ} \mathrm{~mol}^{-1}, \mathrm{PA}\left(\mathrm{C}_{7} \mathrm{H}_{8}\right)=808 \mathrm{~kJ} \mathrm{~mol}^{-1}$ (PA= proton affinity); D. H. Aue, M. T. Bowers in M. T. Bowers (Ed.): Gas Phase Ion Chemistry, Vol. 2, Academic Press, New York 1979, p. 33.

[12] a) M. Jasinski, J. I. Brauman, J. Am. Chem. Soc. 102 (1980) 2906; b) H. Zimmermann, Angew. Chem. 76 (1964) 1; Angew. Chem. Int. Ed. Engl. 3 (1964) 157

[13] The proton-bound dimer $\left[\mathrm{C}_{6} \mathrm{H}_{7}^{\oplus} \cdot \mathrm{C}_{6} \mathrm{H}_{6}\right]$ is more stable by $\Delta H=46 \mathrm{~kJ}$ mol $^{-1}$ than $\mathrm{C}_{6} \mathrm{H}_{7}^{\oplus}$ and $\mathrm{C}_{6} \mathrm{H}_{6} ; \mathrm{M}$. Mautner, P. Hamlet, E. P. Hunter, F. H. Field, J. Am. Chem. Soc. 100 (1978) 5466

\section{Reaction of Ethylene Oxide with Sulfur Dioxide in the Presence of Cesium Ions: Synthesis of $1,3,6,9,2 \lambda^{4}$-Tetraoxathia-2-cycloundecanone}

\section{By Herbert W. Roesky* and Hans Georg Schmidt}

Cyclic homologues of ethylene oxide have attracted great interest because of their unusual complexation properties in the presence of alkali metal ions and other cations. "1] Their properties can be changed by incorporation

["] Prof, Dr. H. W. Roesky, H. G. Schmidt

Institut für Anorganische Chemie der Universität

Tammannstrasse 4, D-3400 Göttingen (FRG) of further heteroatoms. Reactions of ethylene oxide and sulfur dioxide in the presence of catalysts have been well documented. ${ }^{[2]}$ Ethylene sulfite is formed. We have now found that the reaction of ethylene oxide, sulfur dioxide,

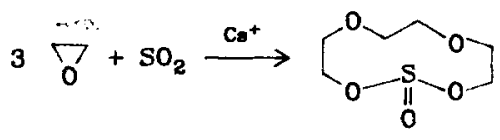

and cesium salts ${ }^{[3]}$ at room temperature leads to higher membered ring compounds, of which the title compound 1 has been isolated in $20 \%$ yield as a white solid. ${ }^{[4]}$

In the field ion mass spectrum, $M^{+}$of $1(\mathrm{~m} / z$ 196) is observed as sole peak. 1 polymerizes on storage at room temperature for several weeks in a sealed flask. Poor quality single crystals were obtained from ethylene oxide and examined X-ray crystallographically. ${ }^{[5]}$

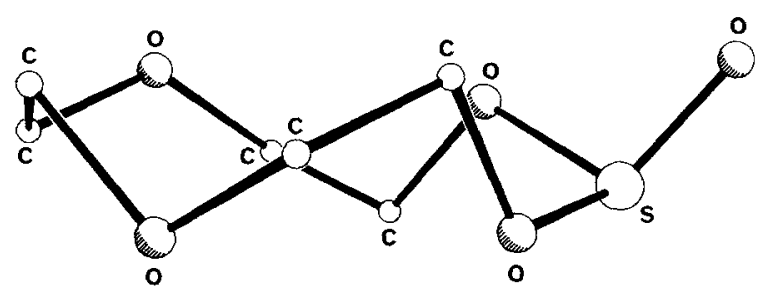

Fig. 1. Crystal structure of 1.

The structure contains two independent conformationally isomeric molecules of 1 (Fig. 1). A final refinement was not possible owing to disorder and/or thermal motions. ${ }^{[6]}$

Received: April 4, 1985 ; Supplemented: May 13, 1985 [Z 1250 lE] German version: Angew. Chem. 97 (1985) 711

[1] C. J. Pedersen, J. Am. Chem. Soc. 89 (1967) 7017; J. Dale, G. Borgen, K Daasvatn, Acta Chem. Scand. B 28 (1974) 378.

[2] Review: G. Dittus in Houben-Weyl, Methoden der Organischen Chemie Bd. 6/3, 4th ed., Thieme, Stuttgart 1965, p. 482; Farbwerke Hoechst AG, Brit. Pat. 753872 (August 1, 1956); Chem. Abstr. 51 (1957) 5821; Chemische Werke Hüls AG, Brit. Pat. 783561 (September 25, 1957); Chem. Abstr. 52 (1958) 5455; G. M. Gibson, C. R. Heald, D. J. Hartley, Brotherton and Co. Ltd., Brit. Pat. 844104 (August 10, 1960); Chem. Abstr. 55 (1961) 11308 ; W. A. Rogers, Jr., J. E. Woekst, R. M. Smith, Dow Chemical Co., U. S. Pat. 3022315 (February 20, 1962); Chem. Abstr. 57 (1962) 5802; A. J. Shipman, ICI Ltd., Brit. Pat. 898630 (June 14, 1962); Chem. Abstr. 57 (1962) 13697; H. Distler, G. Dittus, BASF AG, DBP 1217970 (June 2, 1966); Chem. Abstr. 65 (1966) 7189; H. Distler, BASF AG, DBP I 223397 (August 1966); Chem. Abstr. 65 (1966) 20008.

[3] F. Vögtle, F. Ley, Chem. Ber. 116 (1983) 3000.

[4] $\mathrm{C}_{2} \mathrm{H}_{4} \mathrm{O}(25 \mathrm{~g}, 570 \mathrm{mmol})$ and $\mathrm{SO}_{2}(10 \mathrm{~mL})$ were condensed into two $1.5 \mathrm{~g}$ (4.65 mmol) batches of $\mathrm{CsAsF}_{6}$ in a Schlenk apparatus under vacuum. The mixtures were allowed to warm to room temperature and stirred for $48 \mathrm{~h}$. The volatile products $\mathrm{SO}_{2}, \mathrm{C}_{2} \mathrm{H}_{4} \mathrm{O}$ and dioxane were removed at 20 mbar. Both batches were then combined and distifled in a vacuum. Three fractions were obtained: 1) B.p. $38^{\circ} \mathrm{C} / 0.05$ mbar, $\mathrm{C}_{2} \mathrm{H}_{4} \mathrm{SO}_{3}$, yield $1.9 \mathrm{~g}$ (1.5\%); 2) B.p. $38-65^{\circ} \mathrm{C} / 0.05$ mbar, mixture of $\mathrm{C}_{2} \mathrm{H}_{4} \mathrm{SO}_{3}$ and $\mathrm{SO}_{2}$ with two and three ethylene oxide molecules, $0.8 \mathrm{~g} ; 3)$ B.p. $95^{\circ} \mathrm{C} / 0.01 \mathrm{mbar}, 1$, yield $15 \mathrm{~g}(20.2 \%)$, m.p. $41^{\circ} \mathrm{C}$ - - IR (Nujol): $v=1300,1248,1204,1150$, $1130,1105,1080,1015,905,870 \mathrm{~cm}^{-1}$, and further bands.

[5] $\mathrm{P} 2 / 1 / c, \quad a=11.873(4), \quad b=18.219(6), \quad c=8.981(3) \AA ; \quad \beta=112.11(1)^{\circ}$ $\rho_{\mathrm{calc}}=1.448 \mathrm{~g} / \mathrm{cm}^{3}$ with $M=196.22$ and $Z=8 ; T=-40^{\circ} \mathrm{C}, 2 \theta<40^{\circ}$, direct methods.

[6] G. M. Sheldrick, M. Noltemeyer, private communication. 